\title{
Pasture responses to phosphorus and nitrogen fertilisers on dry hill country
}

\author{
A.G. GILLINGHAM ${ }^{1}$, M.H. GRAY ${ }^{2}$ and D.R. SMITH ${ }^{2}$ \\ ${ }^{1}$ AgResearch, Grasslands Research Centre, Private Bag 11008, Palmerston North
}

${ }^{2}$ AgResearch Poukawa, PO Box 8144, Havelock North

\section{Abstract}

In order to evaluate the relative responsiveness of summer-dry hill pasture to phosphate $(\mathrm{P})$ and nitrogen $(\mathrm{N})$ fertilisers, a large scale field trial was established in southern Hawke's Bay in 1995. Pasture growth rates and species, and soil moisture levels were measured on easy and steep slopes of generally north- and south-facing aspects in two pairs of farmlets with either a Low or High soil $\mathrm{P}$ status, one of each pair also receiving $30 \mathrm{~kg} \mathrm{~N} / \mathrm{ha}$ annually in winter. Soil moisture levels were always higher on south- than on north-facing slopes, the difference being greatest from autumn to spring. However, total annual pasture growth was higher on north aspects because of better winter production, whereas the colder, south aspects produced little pasture at this time. In other seasons, pasture growth was similar on both aspects. Pasture growth was higher on easy than on steep slopes at all times. $\mathrm{P}$ responses occurred from spring to autumn especially on south aspects, and on easy north-facing slopes, which showed a large increase in clover growth. $\mathrm{N}$ responses were best in winter and autumn especially on steep, north aspects and at Low $\mathrm{P}$ conditions. N application depressed clover production, especially in the High $\mathrm{P}+\mathrm{N}$ fertiliser treatment, where there was no net increase in production compared with the High $\mathrm{P}$ treatment. Only tentative conclusions can be made at this time since the pasture is considered to be still in a development phase. However, results suggest that application of $\mathrm{P}$ only to south aspects and moist north slopes, and for steep, north-facing slopes to receive $\mathrm{N}$, plus only limited $\mathrm{P}$, will be the most efficient fertiliser policy.

Keywords: dry hill country, phosphate response, nitrogen response, pasture production, slope, aspect

\section{Introduction}

In most New Zealand farming regions white clover forms the basis of pasture production by fixing nitrogen $(\mathrm{N})$ and supplying it to associated grasses which contribute the majority of growth. In order to stimulate satisfactory clover growth, phosphate $(\mathrm{P})$ fertilisers are applied at levels which are generally regarded as more than adequate for grass requirements. A requirement of this clovergrass partnership is that there is adequate moisture, especially during spring and summer, for vigorous clover growth and persistence.

In summer-dry climates white clover does not persist, and annual clovers form the basis of the pasture legume content. Because of their limited growing period they make a smaller contribution to annual pasture production and associated N fixation (Brock 1973; Simpson 1976) than in more summer-moist climates. The total pasture production may be therefore limited by inadequate $\mathrm{N}$ supply during periods of active growth, as well as moisture shortage in other seasons. It is possible, then, that in some situations, P supply will be more than adequate as a result of routine fertiliser application, but that $\mathrm{N}$ supply is a major factor limiting pasture growth.

In summer-moist hill country Lambert (1986) measured sizable pasture growth responses to both $\mathrm{P}$ and $\mathrm{N}$ fertilisers and Ball \& Field (1982) also concluded that reliable and large $\mathrm{N}$ fertiliser responses are generally obtained from hill pastures in moist environments. They also commented, however, that there was little information available relating to $\mathrm{N}$ responses on hill country in a wider range of environments. That situation has changed little to the present day.

In order to examine relative pasture responses to $\mathrm{P}$ and $\mathrm{N}$ fertilisers in a summer-dry climate, a large scale trial was established in 1994 and began in autumn 1995 on hill country near Waipawa in Hawke's Bay.

\section{The trial site}

The area, about $4 \mathrm{~km}$ west of Waipawa township, comprises north- and south-facing aspects containing both easy $\left(15-20^{\circ}\right)$ and steep $\left(25-30^{\circ}\right)$ slopes on Waipawa stony loam. This averages about $600 \mathrm{~mm}$ in depth and overlies white argillite rock which is exposed on some ridges.

The area had been only lightly grazed for many years previously and the pasture was dominantly browntop with negligible legume content.The mean 
annual rainfall is $800 \mathrm{~mm}$, most regularly falling in winter and early spring; very low rainfall over summer and autumn is possible.

The trial occupies 48 ha divided into 4 farmlets of 12 one hectare paddocks each, receiving contrasting $\mathrm{P}$ and $\mathrm{N}$ fertiliser treatments. These farmlets are balanced so that each is similar in overall slope and aspect. As a result paddocks comprising any one farmlet are not contiguous and are scattered over the total trial area.

Two farmlets receive low annual $\mathrm{P}$ fertiliser rates (Low $\mathrm{P}$ farmlets) as superphosphate to maintain the original Olsen soil P status of 9. The other two farmlets received an initial capital fertiliser dressing and were subsequently maintained at a soil Olsen P level of near 28 (High $\mathrm{P}$ farmlets) by applying the same superphosphate rate as used over the Low $\mathrm{P}$ farmlets plus additional triple super. In addition one each of the Low $\mathrm{P}$ and High $\mathrm{P}$ farmlets received $30 \mathrm{~kg} \mathrm{~N} / \mathrm{ha}$ as urea in winter.The whole area was oversown with white and subterraneum clover seed in autumn 1995 and 1996.

Each farmlet is self contained and stocked with a 65:35 ratio of sheep (5-year-old Romneys) and cattle (18-month-old Friesian/Angus ). The stocking rate and management are designed to fully utilise pasture growth from each farmlet.

\section{Measurements}

Pasture dry matter (DM) production was measured about monthly from a total of 80 plots on representative north- and south-facing easy and steep slopes in each farmlet using a standard trim technique. Pasture species composition was measured from dissected samples as well as from pasture tiller cores ( $50 \mathrm{~mm}$ diameter $)$ taken annually in September-October from the same plots. Autumn (March-May), winter (June-August), spring (September-November) and summer (DecemberJanuary) seasonal and annual pasture production was estimated and results are presented for the initial 3 years. In addition regular gravimetric soil moisture measurements to $75 \mathrm{~mm}$ depth were made.

\section{Statistical analysis}

Pasture production and associated species composition results were subjected to analysis of variance, and the tiller core frequency data were subjected to likelihood ratio statistics (Type 3), from a generalised linear model, assuming quasi-binomial error distribution.

\section{Results}

\section{Soil moisture}

Soil moisture levels varied greatly during each year but were always higher on south- than north-facing slopes (Figure 1). On north-facing slopes soil moisture levels were always higher on easy than on steep slopes, but on south-facing aspects the opposite was often the case (details not shown).

The seasonal pattern of rainfall and soil moisture was similar in 1995 and 1996 in that soil moistures reached a low in November-December and then rewet after regular summer rainfall. In 1997 soil moisture levels remained relatively high until October then declined to a

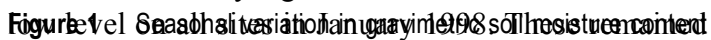
low throug\%obut waightnto $7998 \mathrm{~m}$ depth) on north- and southfacing aspects.

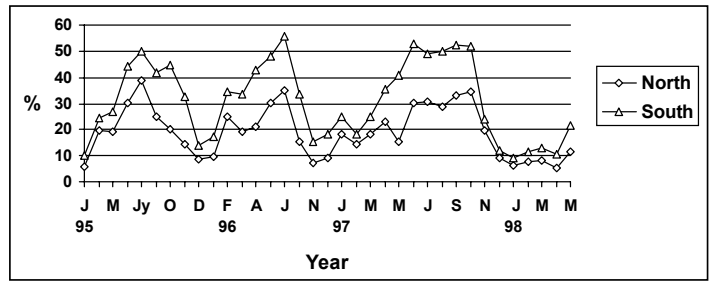

\section{Pasture production}

\section{Seasonal production}

The mean peak pasture production occurred in spring but was also relatively high in summer as a result of the higher-than-average summer rainfall and higher soil moisture levels in January 1996, and also to a lesser extent in January 1997 (Figure 2). Conversely the very low rainfall and soil moistures in summer-autumn 1997-

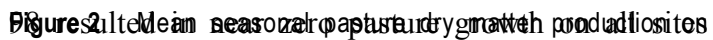
during thesensrastiognsspects and slopes (kg DM/ha).

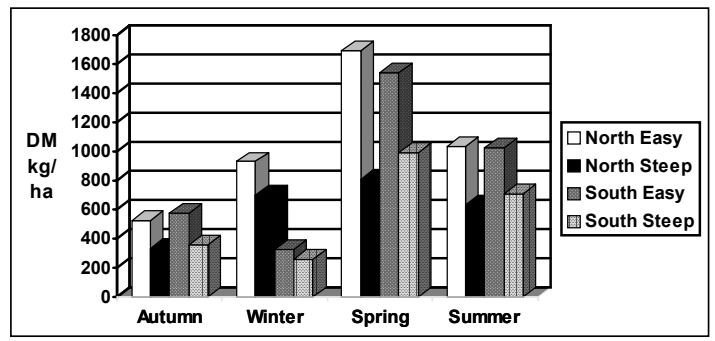

Production was higher on easy than on steep slopes at all times within each aspect; however, pasture growth on north-facing steep slopes in winter was greater than on any areas within the south aspect at this time. Production levels were highest on north-facing easy 
slopes. Both slope and aspect significantly affected total annual pasture production.

\section{Pasture responses to fertiliser}

The High P soil produced more pasture than the Low $P$ soil at all times, totalling an average $1263 \mathrm{~kg} / \mathrm{ha}$ greater annual DM production per year (Figure 3; Table 1).

Total pasture production increased in all seasons at the Low $\mathrm{P}$ level as a result of added $\mathrm{N}$ fertiliser and consequently produced an annual response of $719 \mathrm{~kg} /$ ha from the $30 \mathrm{~kg} / \mathrm{ha}$ of $\mathrm{N}$ fertiliser added. However, addition of $\mathrm{N}$ fertiliser at the High $\mathrm{P}$ level did not further increase total pasture production. This was predominantly owing to a depression in legume production in the High $\mathrm{P}$ plus $\mathrm{N}$ pasture (Table 1) which compensated for the increased grass growth. The interacting effect of $\mathrm{N}$ with $\mathrm{P}$ fertiliser level on legume and on total pasture growth was statistically significant.

The response by total pasture to $\mathrm{P}$ fertiliser was significant for all seasons except winter and also for total annual production. Both grass and clover annual production showed significant responses to $P$ fertiliser.

Pasture showed a complex response pattern to the $\mathrm{P}$ and $\mathrm{N}$ fertilisers applied which was related to aspect and slope (Table 2). Apart from the $\mathrm{N}$ by $\mathrm{P}$ interactions shown in Table 1 for annual production, there were significant seasonal responses in winter and autumn. Pasture responses to $\mathrm{N}$ were greater from steep than easy slopes in winter and annually. The greater $\mathrm{P}$ responses on easy slopes to $\mathrm{P}$ occurred in spring only. Similarly, the response to $P$ fertiliser was greater on the north than south aspect in summer only.

\section{Pasture composition}

Over 3 years pasture white clover content steadily increased in all treatments from a common level in 1994, the greatest increase occurring in the High $\mathrm{P}$ treatments (Table 3). The application of $\mathrm{N}$ fertiliser at both Low and High $\mathrm{P}$ levels resulted in a relative reduction in legume presence, both for white clover and for annual legumes (Other clovers). Subterraneum clover content declined from 1994 to 1997 but this was not related to fertiliser treatment. Browntop occurrence increased in all treatments from 1994 to 1997, but was not affected by fertiliser treatment. Ryegrass frequency increased over the three years, especially where $\mathrm{N}$ had been applied, but was still only at a low level of $1-3 \%$. Slope and aspect affected the presence of all pasture components, except subterraneum clover. There was more white clover, ryegrass and browntop, but less of Other clovers on easy than on steep slopes. Similarly, south aspects had more white clover, browntop and
Figure 3 Seasonal and annual pasture responses to $\mathrm{P}$ and $\mathrm{N}$ fertilisers ( $\mathrm{kg} \mathrm{DM} / \mathrm{ha}$ ).

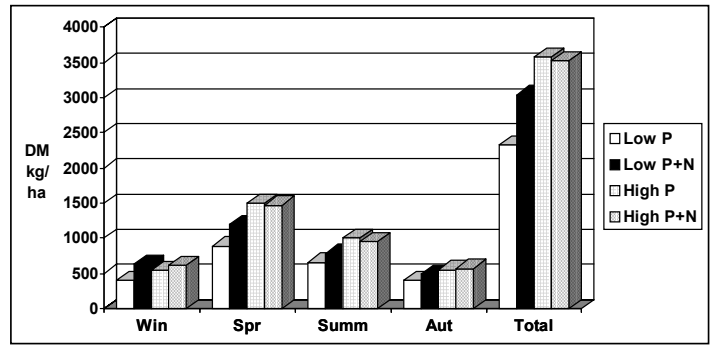

Table 1 Effect of $\mathrm{P}$ and $\mathrm{N}$ fertilisers on grass, clover and total annual DM production ( $\mathrm{kg} / \mathrm{ha})$.

\begin{tabular}{llccc}
\hline & & Grass & Clover & Total \\
\hline Low P & & 2006 & 316 & 2322 \\
Low P+N & & 2839 & 201 & 3040 \\
High P & & 2474 & 1111 & 3585 \\
High P+N & & 2943 & 585 & 3528 \\
Significance: & $\mathrm{P}$ & $* *$ & $* * *$ & $* * *$ \\
& N & $* * *$ & $* *$ & NS \\
& N by P & NS & $*$ & $*$ \\
\hline
\end{tabular}

Table 2 Fertiliser and topographic factors affecting seasonal and annual pasture responses.

\begin{tabular}{lcccccc}
\hline & $\begin{array}{c}\text { Response } \\
\text { Direction }\end{array}$ & Winter & Spring & Summer & Autumn & Annual \\
\hline $\mathrm{P}$ & $\mathrm{H}>$ Low & & $* * *$ & $* * *$ & $* * *$ & $* * *$ \\
$\mathrm{~N}$ & $+\mathrm{N}>$ ON & $* * *$ & & & & \\
$\mathrm{~N}$ by P & $\mathrm{LP}>\mathrm{HP}$ & $*$ & & & $*$ & $*$ \\
Slope & $\mathrm{E}>$ Steep & $* * *$ & $* * *$ & $* * *$ & $* * *$ & $* * *$ \\
$\mathrm{~N}$ by Slope & $\mathrm{St}>$ Easy & $* *$ & & & & $*$ \\
$\mathrm{P}$ by Slope & $\mathrm{E}>$ Steep & & $*$ & & & \\
Aspect & Nth $>$ Sth & $* * *$ & & & & \\
P by Asp't & Sth $>$ Nth & & & $*$ & & \\
\hline
\end{tabular}

Other grasses than north aspects, whereas there was more subterraneum clover and ryegrass on north aspects.

\section{Discussion}

\section{Pasture production}

The emphasis of this trial was to measure pasture responses to $\mathrm{P}$ and $\mathrm{N}$ fertilisers during the part of the year when soil moisture was adequate for pasture growth, i.e., from autumn to spring, and the stock management is organised accordingly.

Average pasture production from hill slopes in this summer-dry environment ranged from only about 2500 to $4000 \mathrm{~kg} \mathrm{DM} / \mathrm{ha} /$ year, and this included two out of three years when there was higher-than-average summer rainfall. This was partly compensated for, however, by a preceding dry spring season in each of those years 
Table 3 Changes in pasture species composition (\% frequency of occurrence) with fertiliser treatment from 1994 to 1997, and with aspect and slope.

\begin{tabular}{|c|c|c|c|c|c|c|c|c|c|}
\hline & \multicolumn{9}{|c|}{$\begin{array}{l}\text { Statistical significance of effects } \\
\quad(1995-97 \text { results only) }\end{array}$} \\
\hline & Low $\mathrm{P}$ & $\begin{array}{l}\text { Low } \\
\mathrm{P}+\mathrm{N}\end{array}$ & High P & $\begin{array}{l}\text { High } \\
\mathrm{P}+\mathrm{N}\end{array}$ & $\mathrm{P}$ & $\mathrm{N}$ & Year & Slope & Aspect \\
\hline \multicolumn{10}{|c|}{ White Clover } \\
\hline 1994 & 2.0 & 1.9 & 2.0 & 3.7 & & & & & \\
\hline 1995 & 8.1 & 2.6 & 12.3 & 7.5 & & & & & \\
\hline 1997 & 15.3 & 10.5 & 34.5 & 23.4 & $* * *$ & $* * *$ & $* * *$ & $\begin{array}{c}* * * \\
(E>S t)\end{array}$ & $\begin{array}{c}* * * \\
(\mathrm{~S}>\mathrm{N})\end{array}$ \\
\hline \multicolumn{10}{|c|}{ Sub. Clover } \\
\hline 1994 & 3.7 & 4.1 & 4.0 & 3.4 & & & & & \\
\hline 1995 & 2.3 & 2.7 & 2.8 & 1.0 & & & & & \\
\hline 1997 & 1.0 & 1.2 & 1.7 & 0.4 & & & * & & $(N>S)$ \\
\hline \multicolumn{10}{|c|}{ Other Clovers } \\
\hline 1994 & 14.6 & 12.2 & 12.8 & 10.7 & & & & & \\
\hline 1995 & 22.2 & 18.7 & 18.1 & 18.4 & & & & & \\
\hline 1997 & 10.9 & 5.3 & 9.1 & 5.0 & & * & $* * *$ & & \\
\hline \multicolumn{10}{|c|}{ Browntop } \\
\hline 1994 & 43.2 & 47.3 & 48.7 & 34.9 & & & & & \\
\hline 1995 & 32.8 & 32.9 & 36.7 & 27.0 & & & & & \\
\hline 1997 & 54.8 & 57.0 & 57.6 & 54.4 & & & $* * *$ & $\begin{array}{c}* * * \\
(E>S t)\end{array}$ & $\begin{array}{c}* * * \\
(\mathrm{~S}>\mathrm{N})\end{array}$ \\
\hline \multicolumn{10}{|c|}{ Ryegrass } \\
\hline 1994 & 2.5 & 1.9 & 0.8 & 1.4 & & & & & \\
\hline 1995 & 1.8 & 0.6 & 0 & 3.0 & & & & & \\
\hline 1997 & 1.4 & 2.4 & 0.8 & 3.5 & & $* * *$ & & $(E>S t)$ & $\begin{array}{c}* * * \\
(N>S)\end{array}$ \\
\hline \multicolumn{10}{|c|}{ Other Grasses } \\
\hline 1995 & 66.1 & 73.4 & 66.4 & 72.8 & & & & & \\
\hline 1997 & 52.6 & 59.9 & 48.2 & 59.1 & & & $* * *$ & $\begin{array}{c}* * * \\
(S t>E)\end{array}$ & $\begin{array}{c}* * * \\
(\mathrm{~S}>\mathrm{N})\end{array}$ \\
\hline
\end{tabular}

(i.e., 1995-96 and 1996-97), especially in 1996, which reduced peak growth. In 1997-98 there was zero summer growth, which contrasted strongly with the previous two years, and accentuated the extreme variation in summer growth that can occur in this environment.

The higher pasture growth on easy than on steep slopes was related, for most times of year, to the higher soil moisture levels on easy slopes. The exception was in winter when there was greater pasture growth on drier, steep, northerly slopes, no doubt because of warmer north aspect temperatures (Gillingham 1974), than on easy slopes on the south aspect during winter.

\section{Fertiliser responses}

The resident pasture was very responsive to both $\mathrm{P}$ and $\mathrm{N}$ fertilisers, both in production and in the associated changes in species composition.

The Olsen P levels of near 28 in the High P treatments would represent a non-limiting $\mathrm{P}$ status for these pastures and require about $25 \mathrm{~kg} \mathrm{P} /$ ha year to maintain. In contrast, the Low P soil at an Olsen P level of 9 needs $12 \mathrm{~kg} \mathrm{P} / \mathrm{ha} /$ year as maintenance fertiliser
(Metherell 1995). The additional pasture growth of $1263 \mathrm{~kg} / \mathrm{ha}$ from the additional $13 \mathrm{~kg} / \mathrm{ha}$ of $\mathrm{P}$ fertiliser averages about $100 \mathrm{~kg} \mathrm{DM} / \mathrm{kg}$ P. This overall average comprised higher responses from easy than steep slopes (i.e., differences of $1670 \mathrm{~kg} / \mathrm{ha}$ on easy cf. $855 \mathrm{~kg} / \mathrm{ha}$ from steep slopes), which therefore provided a proportionately higher DM return from the maintenance $\mathrm{P}$ fertiliser applied. In this environment easy slopes with higher soil moisture levels should receive priority phosphate topdressing.

High levels of DM production response were obtained from urea application in mid to late winter. At the Low $P$ level this averaged $719 \mathrm{~kg} \mathrm{DM} / \mathrm{ha}$ from both easy and steep slopes (i.e., $24 \mathrm{~kg} \mathrm{DM} / \mathrm{kg} \mathrm{N}$ applied).This comprised about $1000 \mathrm{~kg} \mathrm{DM} / \mathrm{ha}$ from steep slopes and $440 \mathrm{~kg} \mathrm{DM} / \mathrm{ha}$ from easy slopes (results not shown). If this is further examined the results show that at the Low $\mathrm{P}$ level, the response was almost $1300 \mathrm{~kg} \mathrm{DM} / \mathrm{ha}$ on north aspect steep slopes and about $700 \mathrm{~kg} \mathrm{DM} / \mathrm{ha}$ on south aspect steep slopes. Therefore, although pasture on all areas showed a significant response to $\mathrm{N}$ fertiliser, the best results were obtained on steep, north aspects with a Low P status. These responses represent about 
$43 \mathrm{~kg} \mathrm{DM} / \mathrm{kg} \mathrm{N}$ fertiliser applied, which compares with $37.8 \mathrm{~kg} \mathrm{DM} / \mathrm{kg} \mathrm{N}$ from steep north west sites in more moist hill country reported by Ball et al. 1976.

The average efficiency of DM response at the Low P level of $24 \mathrm{~kg} \mathrm{DM} / \mathrm{kg} \mathrm{N}$ fertiliser was similar to that recorded by Ball et al. 1976 of $24.8 \mathrm{~kg} \mathrm{DM} / \mathrm{kg} \mathrm{N}$, and by Lambert \& Clark (1986) of $29 \mathrm{~kg} \mathrm{DM} / \mathrm{kg} \mathrm{N}$. However, the detailed results show that much higher efficiencies can be obtained from specific topographic components and preference should be given to these areas if practicable.

\section{Species composition}

White clover was the most responsive sward component to both $\mathrm{P}$ and $\mathrm{N}$ fertilisers. The immediate increase in clover production following $\mathrm{P}$ application to the High P treatments, was a reflection of the initial low $\mathrm{N}$ status of the soil as a result of a history of near zero legume content in the pasture. The effect of $\mathrm{N}$ fertiliser in reducing the clover content in the pasture was a reflection of the compensating effect on $\mathrm{N}$ supply by the legumes, and effectively advanced the development stage of the pasture at each soil P level. The proportional reductions in clover production measured here of about $36 \%$ in Low $\mathrm{P}$ conditions and $47 \%$ in High $\mathrm{P}$ conditions were higher than the reduction of about $15 \%$ in clover content (at about 30 $\mathrm{kg} \mathrm{N} / \mathrm{ha}$ ), and in $\mathrm{N}$ fixation, measured by Luscombe \& Fletcher (1982) in a moist, late spring-summer after $\mathrm{N}$ application to hill pastures in early August. In that study the effect was linear for rates used up to $100 \mathrm{~kg}$ $\mathrm{N} / \mathrm{ha}$ and clearly showed that a single application of $\mathrm{N}$ in early spring can markedly affect clover growth. The mechanism of clover depression can largely be attributed to competition for moisture and P supply, as well as some shading of clover stolons as inadequately utilised pasture accumulates in mid to late spring (Harris \& Thomas 1973; Luscombe et al. 1981).

In this study the effects of $\mathrm{N}$ fertiliser on pasture clover production were evident from year one, but were no doubt reinforced by the re-application of $\mathrm{N}$ fertiliser in subsequent years to the same pastures. In a farm situation $\mathrm{N}$ fertiliser may be applied to new areas each year and so the degree of this effect may be somewhat less. However, the results do indicate that in this environment legumes are sensitive to added $\mathrm{N}$ fertiliser, especially on soils of high P status, where the substitution effect can be marked.

The greater prevalence of white clover on easy slopes and on south aspects reflects the better soil moisture conditions there throughout most of the year. The decline in subterraneum clover content was not related to fertiliser use but more likely reflects the rotational grazing management policy being used, which tends to restrict the opportunity for plants to set and bury seed in late spring-early summer. This occurs better under set stocking management.

It is of interest that the fertiliser treatments have not yet had any marked effect on the grass content of the pasture, at least as measured by the tiller core method. The ryegrass content has increased as a result of the $\mathrm{N}$ fertiliser treatments but still represents only a minor component of the pasture on the hill slopes. Any effects on flatter sites or stock tracks has not been measured.

The conclusions that can be drawn from this study to date must be somewhat tentative since the pasture should be considered to be still in a development stage and further composition changes are expected. However, the results do suggest that the most efficient fertiliser use on dry hill country similar to that at this trial site would be for Olsen P levels on north-facing steep slopes to be maintained at about $8-9$ and for additional fertiliser expenditure on these areas to be put into $\mathrm{N}$ fertiliser. South-facing aspects only, plus moist north-facing slopes, should receive additional $\mathrm{P}$, but no $\mathrm{N}$ fertiliser, except where legume content is low.

\section{ACKNOWLEDGEMENTS}

Ravensdown Fertiliser Cooperative Ltd and Petrochem Ltd are thanked for their financial and management support for the trial; A. Holman and C. Moffat for technical support.

\section{REFERENCES}

Ball, P.R.; Field, T.R.O. 1982. Nitrogen on hill country. pp. 45-64. In: Nitrogen fertilisers in New Zealand Agriculture. P.B. Lynch (ed.) New Zealand Institute of Agricultural Science.

Ball, P.R.; Inglis, J.A.H.; Mauger, J.H. 1976. Tactical application of fertiliser nitrogen to offset a seasonal feed shortage on a heavily stocked sheep ferm in southern Hawke's Bay. Proceedings of the New Zealand Grassland Association 37: 166-181.

Brock, J.L. 1973. Growth and nitrogen fixation of pure stands of three pasture legumes with high and low phosphate. New Zealand journal of agricultural research 16: 483-491.

Gillingham, A.G. 1974. Influence of physical factors on pasture growth on hill country. Proceedings of the New Zealand Grassland Association 35: 77-85.

Harris, W.; Thomas, V.J. 1973. Competition among pasture plants III Effects of frequency and height of cutting on competition between white clover and two ryegrass cultivars. New Zealand journal of agricultural research 24: 49-58.

Lambert, M.G. 1986. Effects of late autumn nitrogen 
application on hill country pastures and sheep production. Proceedings of the New Zealand Grassland Association 47: 211-215.

Luscombe, P.C.; Fletcher, R.H. 1982. Nitrogen fertiliser on grazed hill pastures. Proceedings of the New Zealand Grassland Association 43: 171-181.

Luscombe, P.C.; Grant, D.G.; Thomas, V.J. 1981. Responses of ryegrass, browntop, and an unimproved resident pasture in hill country, to nitrogen, phosphorus, and potassium fertilisers. II Species composition of resident pastures. New Zealand journal of experimental agriculture 9: 237241.

Metherell, A.K., 1995. A model for phosphate requirements for pastures-incorporating dynamics and economics. pp. 18-37. In: The efficient use of fertilisers in a changing environment. L.D. Currie \& P. Loganathan (eds) Occasional Report No. 7, Fertiliser and Lime Research Centre, Massey University.

Simpson, J.R. 1976. Transfer of nitrogen from three pasture legumes under periodic defoliation in a field environment. Australian journal of experimental agriculture and animal husbandry 16: 863-870. 